\title{
EVALUATION OF SUNFLOWER MEAL ON GROWTH AND CARCASS TRAITS OF FINISHING PIGS ${ }^{1}$
}

\author{
Avaliação de farelo de girassol no desempenho e características \\ de carcaca de suínos em terminação \\ Douglas de Carvalho Carellos ${ }^{2}$, José Augusto de Freitas Lima ${ }^{3}$, Elias Tadeu Fialho ${ }^{3}$, \\ Rilke Tadeu Fonseca de Freitas ${ }^{3}$, Hunaldo Oliveira Silva ${ }^{4}$, Patrícia Azevedo Castelo Branco ${ }^{5}$, \\ Zuleide Alves de Souza ${ }^{6}$, José Vieira Neto ${ }^{7}$
}

\begin{abstract}
With the objective to evaluate the influence of increasing levels of inclusion of sunflower meal (SFM) solvent extraction (DM: 92.71\%, CP: 27.50\%, NDF: 43.57\%, ADF: 32.96\%, CF: 25.91\%, EE: 3,08\% and GE: $4390 \mathrm{kcal}$ ) on the performance and carcass characteristics of finishing swine, a performance trial was conducted in the Department of Animal Science of the Federal University of Lavras - MG. A total of 80 crossbred pigs (LD x LW) with initial weight of $62.20 \pm 4.21 \mathrm{~kg}$ were utilized, one barrow and one gilt per experimental unit, allocated in a randomized block design. The treatments were represented by five diets with increasing levels of inclusion (0, 4, 8, 12 and 16\%) of SFM. At the end of the experimental period, all pigs were slaughtered $(99.80 \pm 6.91 \mathrm{~kg})$ and submitted to the carcass evaluation by the Brazilian Method of Carcass Evaluation (ABCS, 1973). The increasing levels of SFM shown a linear reduction $(\mathrm{P}<0.05)$ in the feed intake, therefore all other variables, shown any significant effect. The carcass data evaluation also shown any significant effect $(\mathrm{P}>0.05)$ for any increasing levels of SFM in the diets, however, sex effect was found, in the barrows, which shown higher ETM, P2, AG and RCG and lower AOL in relation to the females In conclusion Sunflower meal should be included up to $16 \%$ in pig diet (isocaloric and isolysinic, basis ) with no major effects on growth performance or carcass traits of finishing pigs
\end{abstract}

Index terms: Swine, sunflower meal, performance, carcass.

\section{RESUMO}

Com o objetivo de avaliar a influência de níveis crescentes de inclusão do farelo de girassol (FG) em rações (MS: 92,71\%; PB: 27,50\%; FDN: 43,57\%; FDA: 32,96\%; FB: 25,91\%) e a atuação deste no desempenho e características de carcaça para suínos em terminação, conduziu-se uma pesquisa no Departamento de Zootecnia da Universidade Federal de Lavras-MG. Foram utilizados 80 suínos mestiços (LD x LW) com peso inicial de 62,20 \pm 4,21 kg, sendo 1 macho e 1 fêmea por baia, distribuídos em um delineamento em blocos ao acaso. As rações apresentaram níveis crescentes de inclusão (0, 4, 8, 12 e 16\%) de FG. Ao final do ensaio de desempenho os 80 suínos foram abatidos $(99,80 \pm 6,91 \mathrm{~kg})$ e submetidos à avaliação de carcaça (ABCS, 1973). Os níveis crescentes de FG proporcionaram redução linear $(\mathrm{P}<0,05)$ no CRMD; para as demais variáveis não se observou efeito significativo. Na avaliação de carcaça, os níveis crescentes de inclusão de FG não proporcionaram efeito significativo $(\mathrm{P}>0,05)$ para as variáveis avaliadas, sendo, entretanto, constatado efeito de sexo, pois os machos apresentaram maiores valores de ETM, $\mathrm{P}_{2}$, AG e RCG e as fêmeas melhor AOL e RPER. Conclui-se que é viável tecnicamente a inclusão de até 16\% de farelo de girassol em rações para suínos na fase de terminação.

Termos para indexação: Suínos, farelo de girassol, desempenho, carcaça.

(Recebido para publicação em 24 de abril de 2003 e aprovado em 24 de novembro de 2004)

\section{INTRODUCTION}

Pig raising has been increasing and adapting to meet the market demand and consumer requirements by offering high quality meat at accessible prices. The energetic and protein feedstuffs, represented mainly by corn and soybean, are used both in human and ani- mal nutrition, but most have been destined to animal feed industry. Nutrition is about $70 \%$ of the final cost of pigs. There is also frequent instab ility in the market regarding offer, nutritional composition and cost of the feedstuffs used in pig diets. This has led producers and researchers to search for alternative feeds that can be utilized in pig diets, reducing costs without damaging animal performance.

1. It is part of Dissertation presented by the first author to the University Federal of Lavras (UFLA) - Brazil.

2. Department of Animal Science - Escola Agrotécnica Federal de São João Evangelista, MG - Brazil - douglascarellos@funopi.org.br

3. Department of Animal Science/UFLA - Lavras, MG - Brazil.

4. Department of Animal Science - Escola Agrotécnica Federal de São Cristóvão, SE - hunald@ufla.br

5. Department of Animal Science - EPAMIG - Brazil - castelobranco78@hotmail.com

6. Department of Animal Science - EPAMIG - Brazil-zusouz@bol.com.br

7. Department of Animal Science - UFLA - Brazil - neto2003@bol.com.br 
Oil consumption is increasing, especially of those oils that present better nutritional characteristics, of which sunflower is outstanding. To meet this demand, sunflower grain production and importation has been increased that has contributed to a greater offer of by-products, mainly sunflower meal that is rich in proteins and fiber, making it a potential alternative ingredient for partial substitution of soybean meal in pig diets.

However, sunflower meal, although its protein is relatively rich in sulfur AA, therefore the lysine is deficient and requires supplementation of this amino acid to meet the nutritional requirements of the animals. Sunflower meal is the main by-product of oil extraction and presents protein quality similar to that of soybean meal, except for the lysine level which is about three times less than in sunflower meal (Lima et al., 1990). Sunflower meal can be used in diets in complement with other lysine-rich feed sources (SILVA, 1990) but the high level of fiber in sunflower meal contributes to a reduction in the concentdiet of digestible energy in the diets. Sunflower meal in substitution of soybean meal requires the addition of vegetable oil and lysine in the diet composition for pigs (CORTAMIRA et al., 2000). This fact implies that the use of sunflower meal should be limited under the risk of reducing the final energy in a diet, requiring more oil for energy supplementation, that could raise the final costs. The nutritional quality of sunflower meal (metabolizable energy, fiber content and protein quality) is affected by the specific processing opediets (MANDARINO, 1997).
Sunflower grain production in Brazil in 2003 was 66 thousand tons (FAGUNDES and SUGFGEFIP, 2002) that represents 23.1 thousand tons of sunflower meal. The increase in production of this oleaginous, allied to the variability in its nutritional composition and the scarcity of data on sunflower meal use in pig nutrition, has triggered interest in researchers about this feedstuff.

The objective of this experiment was to evaluate the effect of sunflower meal inclusion in pigs diets on performance and carcass traits in finishing pigs.

\section{MATERIALS AND METHODS}

Eighty crossbred (Landrace $x$ Large White) pigs ( 40 barrows and 40 gilts) with a $62.2 \pm 3.20 \mathrm{~kg}$ of initial average weight from University Federal of LavrasUFLA swine farm were allotted to five treatments with eight replications of two pigs ( one barrow and one gilt) per replicate on the basis of weight in a randomized complete block design. Ancestry was equalized across treatments. The five treatments were based on five inclusion levels of sunflower meal $0,4,8,12$ e $16 \%$ in the finishing pig diets. The diets were formulated on the base of corn, soybean meal, sunflower meal, soybean oil and synthetic Lysine (Table 1) to meet the nutritional needs of the animals, according to NRC (1998). Composition of the experimental diets are given in Table 2. the diet was formulated to be isoproteic, isocaloric and isolysinic, varying only regarding the inclusion or not of sunflower meal. The treatment diets and water were provided for ad libitum intake throughout the experiment. The experiment lasted $35 \mathrm{~d}$.

TABLE 1 - Chemical composition of the ingredients used in the diets.(as -fed basis)

\begin{tabular}{|c|c|c|c|c|c|}
\hline \multirow[b]{2}{*}{ Items } & \multicolumn{5}{|c|}{ Ingredients } \\
\hline & $\begin{array}{c}\text { Sunflower } \\
\text { Meal }\end{array}$ & Corn & $\begin{array}{c}\text { Soybean } \\
\text { meal }\end{array}$ & Limestone & $\begin{array}{l}\text { Dicalcium } \\
\text { Phosphate }\end{array}$ \\
\hline Dry matter,$(\%)^{1}$ & 92.7 & 87.80 & 89.40 & 98.4 & 98.30 \\
\hline Crude protein $(\%)^{1}$ & 27.5 & 8.30 & 45.80 & - & - \\
\hline Lysine $(\%)^{1}$ & 1.01 & 0.23 & 2.80 & & \\
\hline Crude fibre $(\%)^{1}$ & 25.9 & 2.17 & 6.15 & - & - \\
\hline Ether extract (\%) ${ }^{1}$ & 3.08 & 3.22 & 1.35 & - & - \\
\hline Neutral detergent fibre (\%) ${ }^{1}$ & 43.57 & 8.53 & 1.87 & - & - \\
\hline Acid detergent fibre (\%) ${ }^{1}$ & 32.90 & 4.03 & 7.80 & - & - \\
\hline Calcium $(\%)^{1}$ & 0.22 & 0.03 & 0.37 & 38.2 & 22.40 \\
\hline Phosphorus total (\%) ${ }^{1}$ & 0.67 & 0.25 & 0.63 & - & 23.70 \\
\hline Digestible Energy $\left(\mathrm{Kcal} / \mathrm{kg}^{-1}\right)^{2}$ & 2150 & 3448 & 3450 & - & - \\
\hline
\end{tabular}

${ }^{1}$ Analysis performed at the Nutrition Lab from Animal science Depart. University of Lavras- (AOAC, 1990).

${ }^{2}$ Accord to Fialho et al. (1995). 
TABLE 2 - Ingredients composition of experimental diets for finishing pigs.(as fed basis) ${ }^{\mathrm{a}}$

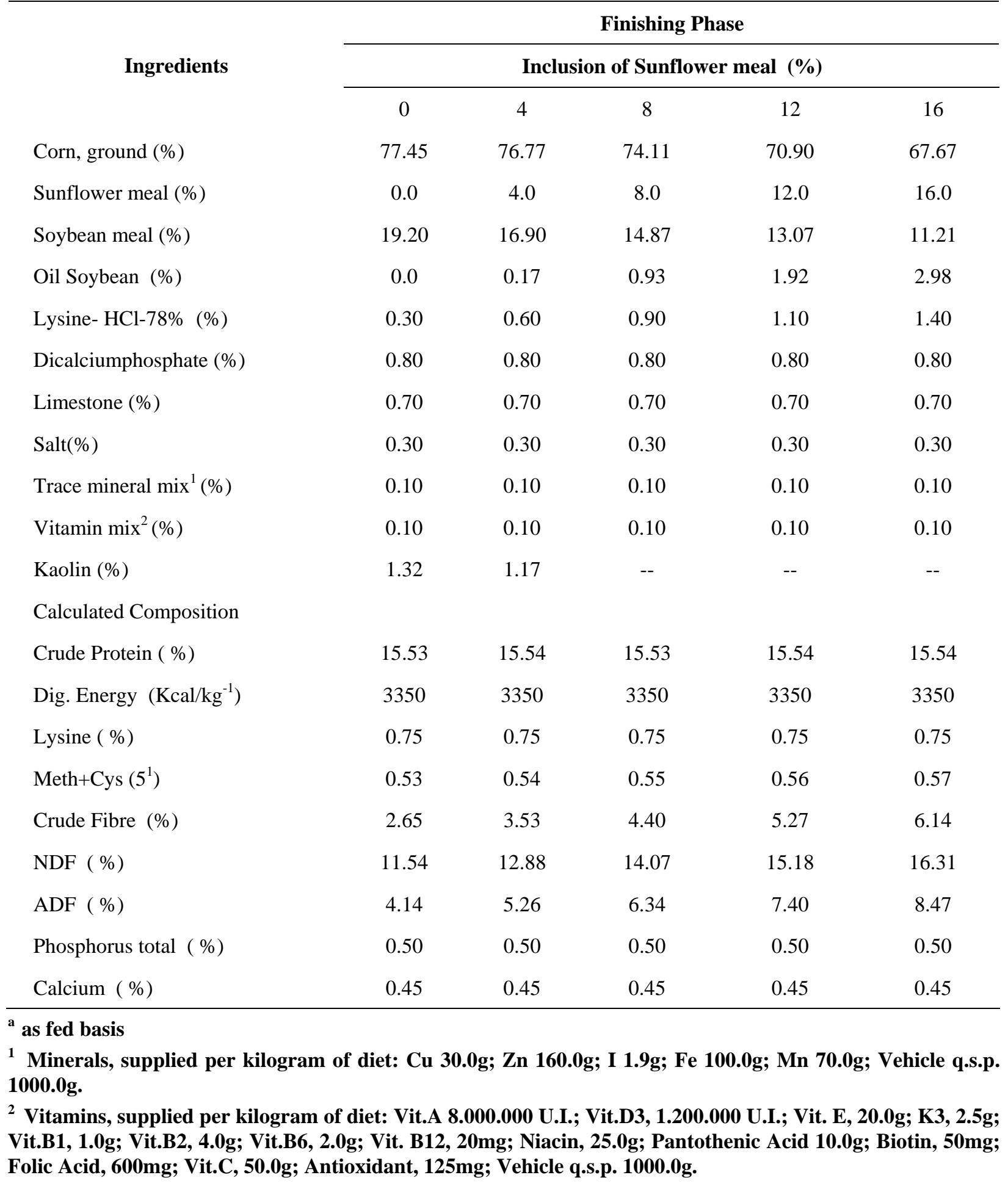

Ciênc. agrotec., Lavras, v. 29, n. 1, p. 208-215, jan./fev. 2005 
The final average weight of the 80 pigs was $99.80 \pm 6.91 \mathrm{~kg}$ and the animal was considered as experimental unit. On the day after the growth trial ended, after 24 hours without diet all pigs were slaughtered by exsanguination and conventional slaughter procedures were followed. Following a 24-h chill, carcass measurements were taken and recorded. The carcass was divided in two halves by a longitudinal cut along the spine. Classification was made according to the Brazilian Method of Carcass Classification (MBCC) described by ABCS (1973). Carcass measurements collected in the cooler included: dressing percent, average backfat thickness (first rib, last rib, and last lumbar vertebra) depths, and at a point $6.5 \mathrm{~cm}$ from the midline at the last rib $\left(\mathrm{P}_{2}\right)$, carcass length. the longissimus loin eye area was measured at a point $3 / 4$ the length of the muscle from the medial side at the 10 th rib, lean:fat ratio (obtained by dividing the fat area by the lean area), ham yield in relation to pork/leg.

Data from growth performance and carcass traits were analyzed by analysis of variance procedures appropriate for a randomized complete block design using GLM procedures of SAS INSTITUTE (2000). The regression analysis were used to determine the effect of inclusion of sunflower in the diet. The statistical model included treatment and replication. Final BW and hot carcass weight data were included as covariates in the analysis for all carcass measures.

\section{RESULTS AND DISCUSSION}

The mean values and respective coefficients of variation (CV) for average daily weight gain (ADW), average daily feed intake (ADFI) and feed conversion (FC) of the pigs at the finishing phase in function of the different inclusion levels of sunflower meal in the pig diets are shown Table 3 .

Sunflower meal inclusion in the diet shown no effect on ADW or feed conversion of the finishing pigs $(\mathrm{P}<0.05)$ but the ADFI of the pigs was affected linearly $(\mathrm{P}<0.05)$ by the inclusion of sunflower meal in the diet and a reduction of 14.6 grams in ADFI was estimated for each percentage unit of sunflower meal included to the diet $\left(y=3.6902-0.0146 x, R^{2}=0.9713\right)$. It seems that the nutritional demands of the pigs were met even with the reduction in feed intake. For the pigs to express all their potential for weight gain, intake must meet their nutritional requirements (WHITTEMORE, 1993). One of the possible causes of the reduction in DFI may have been the higher fiber content that gave a lower density to the diets, with this the intake may have been limited by the distension capacity of the alimentary canal. The presence of high fiber contents in the diets also can reduce intake by excessive volume or by reduced palatability (BRAUDE, 1967, cited by NRC, 1998). Lower feed intake also can occur because of the inclusion of fibrous ingredients with greater water retaining capacity (KYRIAZAKIS and EMMANS, 1995). Voluntary intake by pigs fed freely can be affected by the diet energy (LEWIS, 1991, quoted by PENZ JÚNIOR and VIOLA, 1998). Reduction in feed intake was also observed by Seerley et al. (1974) in growing pigs when they replaced soybean protein with sunflower meal (50 and 10\% ). Also Silva et al. (2002a) found no difference in finishing pig performance with the inclusion of sunflower meal up to the level of 21\% in the diets. Similarly, Wetscherek et al. (1993) reported any difference among treatments when they replaced soybean meal with sunflower meal up to $27 \%$ of the diets. Szabó et al. (2001) also reported no difference in finishing pig performance, when feeding diets based on corn-soybean meal or corn-sunflower meal. Silva et al. (2002b) also observed a quadratic effect for feed intake and weight gain with inclusion of sunflower meal in the diets for finishing pigs. In relation to carcass data (Table 4 ) it was observed no significant effect $(\mathrm{P}<0.05)$ in the carcass dressing percent, carcass length, ham yield in relation pork/leg and average backfat thickness with the inclusion of sunflower meal in the diet for finishing pigs. However, a difference $(\mathrm{P}<0.01)$ was observed between the sexes, and the gilts shown better carcass traits when compared with the barrows carcass.

No significant effect was observed $(\mathrm{P}<0.05)$ for average backfat thickness, longissimus eye loin area, lean:fat ratio with the inclusion of sunflower meal in the diets ( Table 5 ) . However, there was a significant difference between the sexes, and the gilts shown better $(\mathrm{P}<0.05)$ longissimus loin eye area and less average backfat thickness and carcass fat as well as lower lean:fat ratio $(\mathrm{P}<0.05)$ than barrows.

The reduction in energy intake by feeding restriction or by dilution of the energetic contents in diets with sunflower meal increasing the supply of fiber content, reduces fat deposition and increases lean production accord to Tribble (1991). Also Dierick et al. (1989) have been reported the reduction in 10th backfat thickness and body fat and the increase in muscle mass production result in improved carcass quality, although they are associated with less body weight gain in pigs fed on fibrous diets. 
TABLE 3 - Effect of sunflower meal on performance of finishing pigs.

\begin{tabular}{|c|c|c|c|c|c|c|}
\hline \multirow[t]{2}{*}{ Items } & \multirow[b]{2}{*}{$0 \%$} & \multicolumn{3}{|c|}{ Inclusion of Sunflower meal (\%) } & \multicolumn{2}{|c|}{$\mathrm{CV}^{3}(\%$} \\
\hline & & $4 \%$ & $8 \%$ & $12 \%$ & $16 \%$ & \\
\hline Initial BW (kg) & 62.00 & 62.58 & 62.18 & 61.92 & 62.32 & 1.71 \\
\hline Final BW $(\mathrm{kg})^{1}$ & 99.80 & 100.30 & 100.74 & 99.17 & 99.06 & 3.45 \\
\hline ADG $(\mathrm{kg})^{1}$ & 0.945 & 0.943 & 0.964 & 0.931 & 0.919 & 8.68 \\
\hline ADFI $(k g)^{2}$ & 3.70 & 3.61 & 3.58 & 3.51 & 3.46 & 5.38 \\
\hline FC $(\mathrm{kg} / \mathrm{kg})^{1}$ & 3.92 & 3.83 & 3.72 & 3.77 & 3.85 & 8.19 \\
\hline
\end{tabular}

${ }^{1}$ No- Significant regression were found $(P>0.05)$ in function of sunflower meal inclusion in the diets. ${ }^{2}$ Significant regression were found $(P<0.05)$ in function of sunflower meal inclusion in the diets.

${ }^{3}$ Coefficient of variation.

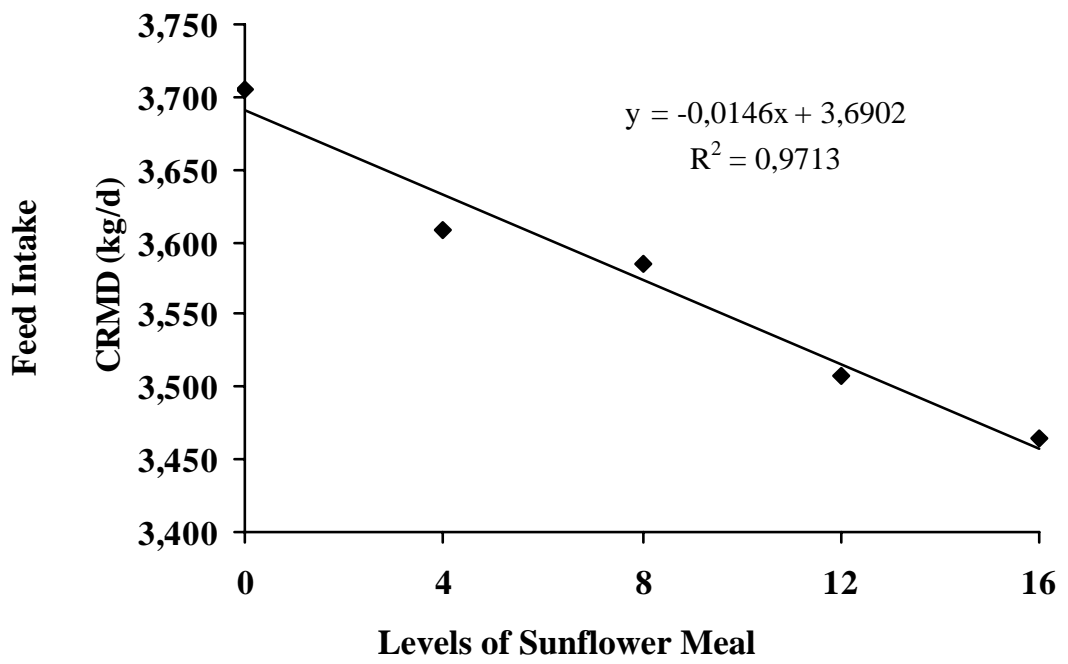

FIGURE 1 - Feed Intake of diets with sunflower meal for finishing pigs. 
TABLE 4 - Effect of sunflower meal on carcass dressing \% (CD\%), Carcass length (CL), ham yield in relation to pork/leg (HY) Average backfat thickness (ABT) o finishing pigs.

\begin{tabular}{|c|c|c|c|c|c|}
\hline \multirow{2}{*}{\multicolumn{2}{|c|}{$\begin{array}{c}\text { Inclusion of Sunflower meal } \\
\qquad(\%)^{1}\end{array}$}} & \multicolumn{4}{|c|}{ Item } \\
\hline & & CD (\%) & CL (cm) & $(\mathrm{HY})(\%)$ & $\mathrm{ABT}(\mathrm{cm})$ \\
\hline \multicolumn{2}{|c|}{0} & 81.88 & 93.69 & 30.33 & 3.08 \\
\hline \multicolumn{2}{|c|}{4} & 81.80 & 92.76 & 29.60 & 3.30 \\
\hline \multicolumn{2}{|c|}{8} & 81.70 & 94.04 & 29.74 & 3.14 \\
\hline \multicolumn{2}{|c|}{12} & 81.82 & 93.58 & 29.95 & 3.32 \\
\hline \multicolumn{2}{|c|}{16} & 81.90 & 92.09 & 30.17 & 3.18 \\
\hline \multirow[t]{2}{*}{$\mathrm{SEX}^{2}$} & Gilt & $81.89^{a}$ & $92.90^{\mathrm{a}}$ & $30.71^{\mathrm{a}}$ & $2.93^{\mathrm{b}}$ \\
\hline & Barrow & $81.75^{\mathrm{a}}$ & $93.56^{\mathrm{a}}$ & $29.20^{\mathrm{b}}$ & $3.48^{\mathrm{a}}$ \\
\hline \multicolumn{2}{|c|}{ CV (\%) } & 1.09 & 3.01 & 4.79 & 13.34 \\
\hline
\end{tabular}

${ }^{1}$ No- Significant regression were found $(P>0.05)$ in function of sunflower meal inclusion in the diets.

${ }^{2}$ Means without common superscript in the same column differ $(\mathbf{P}<\mathbf{0 . 0 1})$.

${ }^{3}$ Coefficient of Variation

TABLE 5 - Effect of sunflower meal on carcass backfat thickness in $\mathrm{P}_{2},,\left(\mathrm{P}_{2}\right)$ Longissimus eye loin eye area (LELA), carcass fat ( CF) and lean:fat ratio (L:F) of finishing pigs.

\begin{tabular}{|c|c|c|c|c|c|}
\hline \multirow{2}{*}{\multicolumn{2}{|c|}{$\begin{array}{c}\text { Inclusion of Sunflower meal }{ }^{1} \\
(\%)\end{array}$}} & \multicolumn{4}{|c|}{ Item } \\
\hline & & $\mathbf{P}_{2}(\mathrm{~cm})$ & $\operatorname{LELA}\left(\mathrm{cm}^{2}\right)$ & $\mathrm{CF}\left(\mathrm{cm}^{2}\right)$ & $\mathbf{L}: \mathbf{F}$ \\
\hline \multicolumn{2}{|c|}{0} & 2.62 & 38.55 & 26.49 & 0.72 \\
\hline \multicolumn{2}{|c|}{4} & 2.50 & 39.03 & 26.41 & 0.68 \\
\hline \multicolumn{2}{|c|}{8} & 2.50 & 37.80 & 25.83 & 0.69 \\
\hline \multicolumn{2}{|c|}{12} & 2.51 & 37.75 & 26.16 & 0.71 \\
\hline \multicolumn{2}{|c|}{16} & 2.49 & 38.28 & 26.85 & 0.71 \\
\hline \multirow[t]{2}{*}{$\mathrm{SEX}^{2}$} & Gilt & $2.22^{\mathrm{b}}$ & $39.30^{\mathrm{a}}$ & $24.27^{\mathrm{b}}$ & $0.63^{b}$ \\
\hline & Barrow & $2.83^{\mathrm{a}}$ & $37.27^{\mathrm{b}}$ & $28.43^{\mathrm{a}}$ & $0.77^{\mathrm{a}}$ \\
\hline \multicolumn{2}{|c|}{$\mathrm{CV}(\%)^{3}$} & 23.57 & 10.69 & 15.27 & 20.98 \\
\hline
\end{tabular}

${ }^{1}$ No- Significant regression were found $(P>0.05)$ in function of sunflower meal inclusion in the diets.

${ }^{2}$ Means without common superscript in the same column differ $(\mathbf{P}<\mathbf{0 . 0 1})$.

${ }^{3}$ Coefficient of Variation 
These data also do not agree with data obtained in our experiment, where the inclusion of sunflower meal did not affect any carcass traits analyzed. There was no reduction in the energetic values of the diets or of fat thickness in the carcasses with sunflower meal inclusion, even though there was reduced feed intake. The results obtained in the present experiment were similar to those obtained by Seerley et al. (1974) who reported no effects in the carcass characteristics when finishing pigs were fed diets with soybean meal replaced with sunflower meal. Shelton et al. (2001) also reported no differences for carcass traits when they compared corn-soybean diets with corn-sunflower meal diets. Similarly, Silva et al. (2002a) also reported no differences in the carcass traits with inclusion of sunflower meal for finishing pigs. The highest values observed in longissimus loin eye area and higher 10th backfat thickness and lower lean:fat ratio $(\mathrm{P}<0.05)$ presented in the barrows may be related to the physiology and higher feed intake compared to the gilts, thus increasing fat deposition. Fat deposition in the carcass is mainly influenced by the energetic intake. Energy that is ingested beyond that necessary for maintenance and protein deposition is used to synthesize fat (WHITTEMORE, 1993) although muscular growth is always accompanied by a minimum of fat. The potential for muscle growth can vary with the sex and genotype of the animal (BIKKER and BOSCH, 1996). In a similar study Silva et al. (2002a) also observed greater fat deposition in the barrows. Also, Silva et al. (2002c) observed greater percentage of lean meat for barrows when sunflower meal was included in the pig diets.

Accord to the results in this experiment, research is needed to provide a better understanding of the physiological mechanisms of muscle growth and to explain some conflicting results in studies that have been reported thus far.

\section{CONCLUSION}

Sunflower meal should be included up to $16 \%$ in pig diet (isocaloric and isolysinic, basis ) with no major effects on growth performance or carcass traits of finishing pigs .

\section{REFERENCES}

ASSOCIAÇÃO BRASILEIRA DOS CRIADORES DE SUÍNOS. Método brasileiro de classificação de carcaça. Estrela, 1973. 17 p.
ASSOCIATION OF OFFICIAL ANALYTICAL CHEMISTS. Official method of analysis. Washington, 1990.

BIKKER, P.; BOSCH, M. Nutrient requirements of pigs with high genetic potential for lean gain. In: SIMPÓSIO INTERNACIONAL SOBRE EXIGÊNCIAS NUTRICIONAIS DE AVES E SUÍNOS, 1996, Viçosa. Anais... Viçosa: UFV, 1996. p. 223-240.

CORTAMIRA, O.; GALlEGO, A.; KIM, S. W. Evaluation of twice decorticated sunflower meal as a protein source compared with soybean meal in pig diets. Asian-Australian Journal Animal Science, Suweon, v. 13, n. 9, p. 1296-1303, Sept. 2000. Abstract.

DIERICK, N. A. et al. Approach to the energetic importance of fibre digestion in pigs: I. importance of fermentation in the overall energy supply. Animal Feed Science Technology, Amsterdam, v. 23, n. 1/3, p. 141167, Apr. 1989.

FAGUNDES, M. H.; SUGFGEFIP. Sementes de girassol: alguns comentários. 2002. Disponível em: $<$ http://www.conab.gov.br/politicaagricola/conjunturase manal/especiais/sementesgirassol2.htm $>$. Acesso em: 16 jan. 2003.

FIALHO, E. T.; BARBOSA, H. P.; ALBINO, L. F. T. Chemical composition and digestibility of some Brazilian feedstuffs by usin the metabolism assay. Animal Feed Science Technology, Amsterdam, v. 26, n. 1/3, p. 141167, 1995.

KYRIAZAKIS, I.; EMMANS, G. C. The voluntary feed intake of pigs given feeds based on wheat bran, dried citrus pulp and grass meal, in relation to measurements of feed bulk. The British Journal of Nutrition, Cambridge, v. 73, n. 1, p. 191-207, Jan. 1995.

LIMA, G. J. M. M. et al. Tamanho da partícula afeta a digestibilidade do farelo de girassol em suínos. Brasília: EMBRAPA-CNPSA, 1990. 2 p. (Circular técnica, 153).

MANDARINO, J. M. G. Derivados protéicos do girassol. In: REUNIÃO NACIONAL DE PESQUISA DO GIRASSOL, 12., 1997, Campinas, SP. Resumos... Campinas: Fundação Cargill, 1997. p. 8-10.

NATIONAL RESEARCH COUNCIL. Nutrients requirements of swine. 10. ed. Washington: National Academic of Science, 1998. 186 p. 
PENZ JÚNIOR, A. M.; VIOLA, E. S. Nutrição. In: SOBESTIANSKY, J. et al. Suinocultura intensiva. Brasília: [s.n.], 1998. cap. 3, p. 45-64.

SAS INSTITUTE. SAS user's guide: basics. Cary, 2000.

SEERLEY, R. W. et al. Sunflower meal as a replacement for soybean meal in growing swine and rat diets. Journal of Animal Science, Champaign, v. 38, n. 5, p. 947-953, May 1974.

SHELTON, J. L. et al. Effect of different protein sources on growth and carcass traits in growingfinishing pigs. Journal of Animal Science, Champaign, v. 79, n. 9, p. 2428-2435, Sept. 2001.

SILVA, M. N. A cultura do girassol. Jaboticabal: FUNEP, 1990. $67 \mathrm{p}$.

SILVA, C. A. et al. Farelo de girassol na alimentação de suínos em crescimento e terminação: digestibilidade, desempenho e efeitos na qualidade de carcaça. Revista Brasileira de Zootecnia, Viçosa, v. 31, n. 2, p. 982990, 2002a. Suplemento.

SILVA, C. A. et al. Grão de girassol na alimentação de suínos em crescimento e terminação: digestibilidade e desempenho zootécnico. In: CONGRESSO LATINO AMERICANO DE SUINOCULTURA, 2002, Foz do Iguaçu. Anais... Foz do Iguaçu: [s.n.], 2002b. p. 221-222.

SILVA, C. A. et al. Grão de girassol na alimentação de suínos em crescimento e terminação e efeito na qualidade de carcaça. In: CONGRESSO LATINO AMERICANO DE SUÍNOCULTURA, 2002, Foz do Iguaçu. Anais... Foz do Iguaçu: [s.n.], 2002c. p. 223-224.

SZABÓ, C. et al. The effect of dietary protein source and lysine: DE ratio on growth performance, meat quality, and body composition of growing-finishing pigs. Journal of Animal Science, Champaign, v. 79, n. 11, p. 2857-2865, Nov. 2001.

TRIBBLE, L. F. Feeding growing-finishing pigs. In: MILLER, E. R.; ULLREY, D. E.; LEWIS, A. J. (Eds.). Swine nutrition. Butterworth: Heinemann, 1991. p. 506-509.

WETSCHEREK, W.; LETTER, F.; KNAUS, W. Use of dehuleed sunflower meal in diet for pig ffattenning. Bodenkultur, Vienna, v. 44, n. 1, p. 89-97, 1993.

WHITTEMORE, C. T. The science and practice of pig productive. Longman: Scientific e Technical, 1993. $661 \mathrm{p}$. 